\title{
Calorimetric Determination of Free Energy Efficiency in Nitrobacter winogradskyi
}

\author{
By A. DESSERS, C. CHIANG AND H. LAUDELOUT \\ Laboratoire de Physico-chimie Biologique, \\ University of Louvain, Belgium
}

(Accepted for publication 15 September 1970)

\begin{abstract}
SUMMARY
The heat evolved by growing Nitrobacter is a measure of its efficiency of free energy utilization which is related to the apparent molar heat of substrate oxidation. The maximum free energy efficiency was about $50 \%$ of a total free energy change of $-I 7.5 \mathrm{kcal} . / \mathrm{mole}$. The molar growth yield decreased rapidly with the age from $10^{7}$ to $3 \times 10^{6}$ organisms $/ \mu$ mole substrate. The free energy needed for the synthesis of one Nitrobacter varied from 0.45 nanocalories at the onset of growth to $2 \cdot 9$ at later stages. From these values and the bacterial enthalpy content its negentropy content can be calculated.
\end{abstract}

\section{INTRODUCTION}

Calorimetric studies of the growth of heterotrophic micro-organisms have been summarized recently (Forrest, 1970). No calorimetric study of growth of chemoautotrophic bacteria has been reported. There should be a distinct advantage in using these organisms since the free energy corresponding to the oxidation of I mole of substrate is accurately known; for heterotrophs the available free energy has to be estimated as the difference between the free energy of the substrate and that of metabolic products not incorporated into cell substance.

The present study reports a comparison of the calorimetrically measured efficiency of free energy utilization with the molar growth yield of the autotrophic bacterium Nitrobacter winogradskyi which uses as sole energy source the oxidation of nitrite to nitrate. Previous studies (Laudelout, Simonart \& Van Droogenbroeck, I968) on the utilization of free energy by that micro-organism were limited to resting suspensions; a difficulty being the high variability of the observed molar heat of substrate oxidation. A similar observation has been made by Poe \& Estabrook (I968) while measuring the molar heat of substrate oxidation by mitochondria when the oxidation process occurred through NAD.

\section{METHODS}

Nitrobacter winogradskyi (a strain originally received from Professor Engel, Hamburg, West Germany) was grown at various nitrite concentrations in the following nutrient solution: $\mathrm{NaNO}_{2}, 20$ to $100 \mathrm{~mm} ; \mathrm{Na}_{2} \mathrm{HPO}_{4}$, I8 mM; $\mathrm{KH}_{2} \mathrm{PO}_{4}, 2 \mathrm{mM} ; \mathrm{MgSO}_{4}$, $0.04 \mathrm{~mm} ; \mathrm{ZnSO}_{4} .7 \mathrm{H}_{2} \mathrm{O}, 20 \mu \mathrm{g}$.; $\mathrm{CuSO}_{4} \cdot 7 \mathrm{H}_{2} \mathrm{O}, 20 \mu \mathrm{g}$; $\mathrm{Na}_{2} \mathrm{MoO}_{4} .2 \mathrm{H}_{2} \mathrm{O}, 20 \mu \mathrm{g}$.; $\mathrm{FeSO}_{4} \cdot 7 \mathrm{H}_{2} \mathrm{O}, 5 \mathrm{mg}$; EDTA, $5 \mathrm{mg}$./1. This solution was sterilized by autoclaving at $\mathrm{I} 2 \mathrm{I}^{\circ}$. The final $\mathrm{pH}$ was $7 \cdot 6$. Seven $\mathrm{ml}$. portions were inoculated in the cell of a Calvet microcalorimeter (Calvet \& Prat, I956) with about $\mathrm{I} \times 10^{6}$ bacteria. The lag of the 
culture (a few hours) was always longer than the time necessary for thermal equilibration at the calorimeter temperature, i.e. $30^{\circ}$.

The culture was aerated by bubbling sterile air saturated with water vapour at the temperature of the calorimeter. The Calvet instrument is a differential calorimeter with two identical sets of thermocouples mounted around two cells in opposition, so a stream of air was bubbled through the control cell containing only distilled water. The two air streams were balanced with valves of the NUPRO (Cleveland, Ohio, U.S.A.) type before growth started. The heat evolved was recorded until the return of the trace to the base line indicated that the substrate had been completely oxidized. The calorimetric cell was then dismantled, the disappearance of nitrite checked and the number of bacteria counted, first by a direct microscopic method similar to that of Jones \& Mollison (I948) and later with a Coulter counter. The model ' $\mathrm{FN}$ ' of this instrument was used with a $30 \mathrm{~nm}$. aperture, the electrolyte was I $\mathrm{M}-\mathrm{NaCl}$, the aperture current I. $43 \mathrm{~mA}$. The calibration of the threshold values with respect to the volume of the particles was made with a monodisperse suspension of polystyrene beads with a mean diameter of $\mathrm{I} \cdot 099 \pm 0.006 \mu \mathrm{m}$.

To study effects of age without having to sample the growth vessel, cultures of initial nitrite concentrations from 5 to $100 \mathrm{~mm}$ were examined. Admittedly the results would not be strictly comparable if the initial substrate concentration influenced the growth process in any way other than by extending the number of possible generations. This, however, does not seem to be the case since the lag was not appreciably influenced by the initial substrate concentration within the limits studied here. Furthermore, end product accumulation slows down the rate of growth to a negligible value only in the upper range of concentrations used here, as evidenced by Fig. 2 B. Unless the maintenance energy expended during the growth of Nitrobacter is considerably larger than for heterotrophic bacteria, slowing down the rate of growth due to nitrate accumulation will be without noticeable effect on the number of generations.

Non-bacterial organic matter excreted into the culture solution was estimated as follows: cylindrical culture vessels aerated through a fritted glass bottom plate and containing about $200 \mathrm{ml}$. culture solution with $30 \mathrm{~mm}$ nitrite were inoculated to $\mathrm{I} \cdot 5 \times 10^{6} / \mathrm{ml}$. bacteria. When the initial nitrite had been oxidized, $20 \mathrm{~mm}$ more was added. When the nitrite had disappeared, the number of cells/unit volume was counted and a Millipore filtrate was prepared and freeze-dried. Its organic carbon content was determined with a $\mathrm{CHN}$-analyser (Hewlett-Packard). To a parallel culture further additions of nitrite were made until the total amount oxidized was $100 \mathrm{~mm}$. This pulse-feeding technique has the advantage of ensuring rapid and uniform growth of the parallel cultures. This was especially important for the cultures which were observed after the complete usage of $100 \mathrm{~mm}$ nitrite. It is unlikely that the pulse-feeding technique vitiates the comparison with the cultures in the calorimeter since determination of non-bacterial organic matter in calorimeter cultures at $100 \mathrm{~mm}$ initial concentration gave a value which was comparable to that observed in the larger scale cultures, albeit imprecise due to the small amount of culture solution which could be analysed.

\section{Molar growth yield}

\section{RESULTS}

The molar growth yield decreased with the initial nitrite concentration and became constant between 50 and $100 \mathrm{~mm}$ nitrite at $3 \times 10^{6}$ organisms $/ \mu$ mole nitrite (Fig. I). The 
molar growth yield observed at very low substrate concentrations was not accurate, but extrapolation of the curve of Fig. I gives a limiting value of about $10^{7}$ bacteria/ $\mu$ mole. Thus, presumably, at the onset of growth the yield was more than three times higher than at later stages. The average dry weight was $0.9 \times 10^{-13} \mathrm{~g}$. $/$ bacterium as determined by a gravimetric method on suspensions containing known numbers.

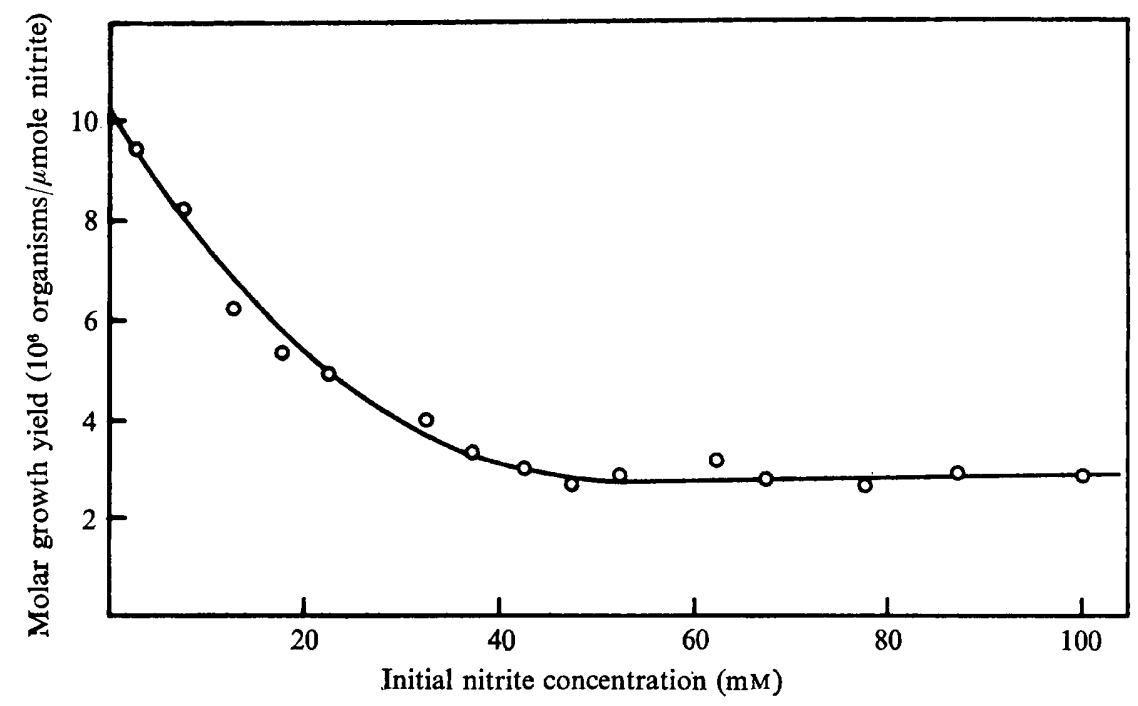

Fig. I. Molar growth yield of Nitrobacter as a function of the initial substrate concentration in the nutrient solution.

The average volume of the bacteria according to the Coulter counter volume spectra determinations was $0.25 \mu \mathrm{m} .^{3}$, i.e. $2.5 \times 10^{-13} \mathrm{~g}$. for a wet bacterium of specific gravity $\mathrm{I}$. The volume spectrum changed but little during growth and so did presumably the average weight/bacterium. If a bacterium contains 75 to $80 \%$ water (Porter, I946) an average volume of $0.25 \mu \mathrm{m} .{ }^{3}$ is equivalent to a dry weight of about $0.7 \times 10^{-13} \mathrm{~g}$./ bacterium.

The molar growth yield of Nitrobacter cultures thus varied from $700 \mathrm{mg} . / \mathrm{mole}$ of substrate at the onset of growth to $210 \mathrm{mg}$./mole at later stages.

\section{Molar heat of substrate oxidation during growth}

Fig. 2 shows two recordings of the heat flux for cultures with $24.5 \mathrm{~mm}$ and $96 \cdot 0 \mathrm{~mm}$ nitrite. Integration of the curves gives the total heat evolved. At the higher concentration, the rate of heat evolution increased and then remained constant for a few hours. Since the calorimeter registers the rate of heat evolution, the constancy showed that growth had ceased or that the total amount of nitrite oxidase was constant and oxidized the substrate at a constant rate.

Apparent molar heats of nitrite oxidation were calculated from the amount of heat evolved and the amount of nitrite initially present in the calorimeter cell. To simplify discussion, these molar heats have been recalculated as efficiency of free energy utilization according to the relation:

$$
\text { Efficiency of free energy utilization }=\frac{\Delta H_{0}-\Delta Q}{\Delta G_{0}} \times 100 \%,
$$


where $\Delta Q$ is the observed molar heat of substrate oxidation expressed, by convention, as a negative value in kcal./mole, $\Delta H_{0}=-24.2 \mathrm{kcal} . / \mathrm{mole}$ and $\Delta G_{0}=-17.8 \mathrm{kcal} . /$ mole for $\mathrm{NO}_{2}{ }^{\prime} \rightarrow \mathrm{NO}_{3}{ }^{\prime}$ (Fig. 3). No accurate estimate of the free energy utilization could be obtained below an initial substrate concentration of $20 \mathrm{mM}$. The extrapolated value to zero initial concentration, i.e. $26 \%$, is thus more unreliable than that obtained from Fig. 3 .

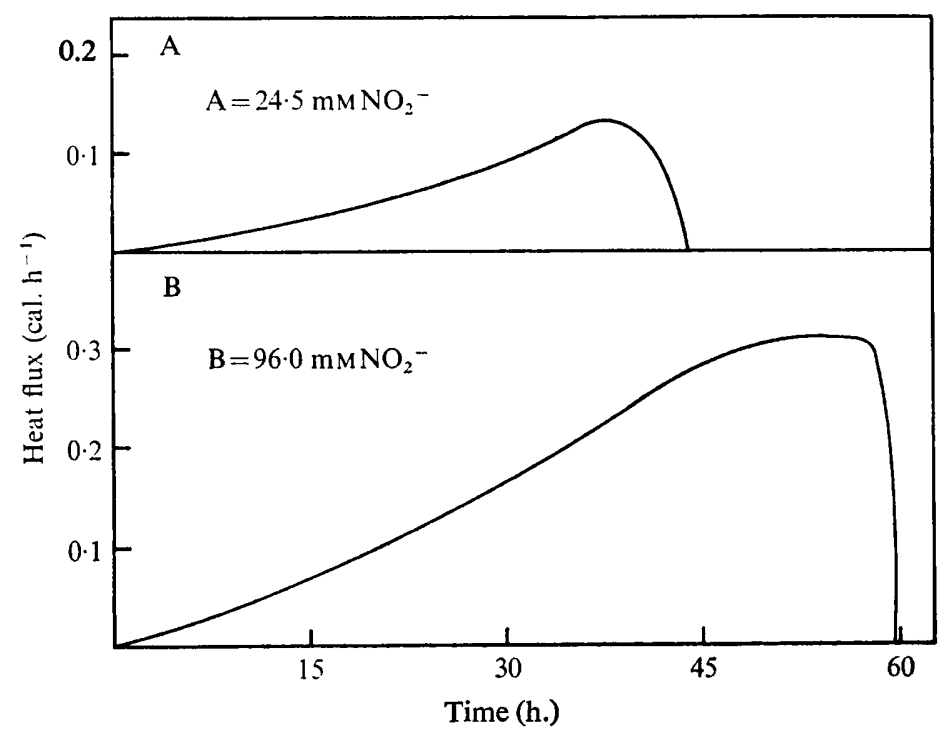

Fig. 2. Rate of heat flow from growing cultures of Nitrobacter for two cultures $(7 \mathrm{ml}$.) at different initial nitrite concentrations.

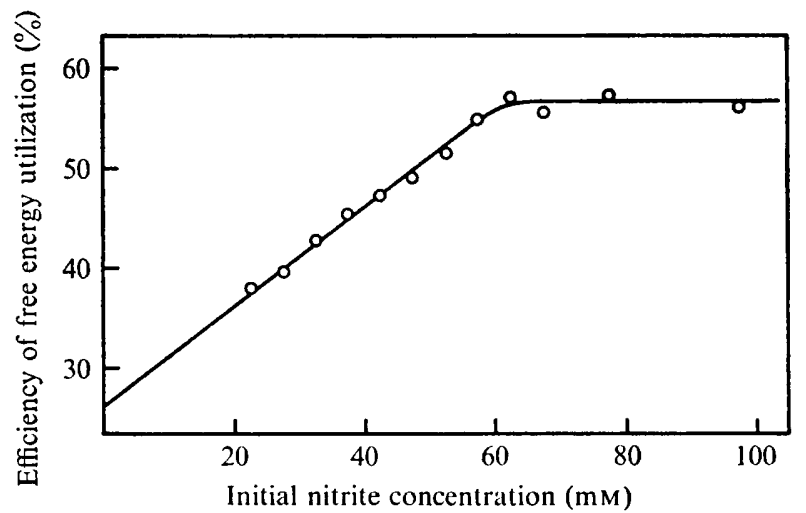

Fig. 3. Efficiency of free energy utilization calculated from the molar heat of substrate oxidation against initial concentration of nitrite.

\section{Production of extracellular organic matter during growth}

Table I shows that a large fraction of the $\mathrm{CO}_{2}$ fixed by Nitrobacter appeared as extracellular carbon: $50 \%$ after the oxidation of $50 \mathrm{~mm}$ nitrite and $59 \%$ after the oxidation of $100 \mathrm{~mm}$. The yield of extracellular $\mathrm{C}$ became practically constant after 
$50 \mathrm{mmoles} / \mathrm{l}$. had been oxidized. This observation merely confirms the more detailed results shown in Fig. 3 on the constancy of the free energy utilization between 50 and I00 $\mathrm{mm}$ initial nitrite concentration.

\section{Table I. $\mathrm{CO}_{2}$ fixation by a Nitrobacter culture after oxidation of a given amount of nitrite}

\begin{tabular}{|c|c|c|c|c|}
\hline \multirow{2}{*}{$\begin{array}{l}\text { Amount of } \\
\text { nitrite oxidized } \\
\mu \mathrm{mole} / \mathrm{ml} .\end{array}$} & \multicolumn{2}{|c|}{ Bacterial density in } & \multirow[b]{2}{*}{$\begin{array}{c}\text { Extracellular C } \\
(\mu \mathrm{g} . / \mathrm{ml} .)\end{array}$} & \multirow[b]{2}{*}{$\begin{array}{l}\text { Total } \mathrm{CO}_{2} \text { reduced } \\
\text { as } \mathrm{C}(\mu \mathrm{g} . / \mathrm{ml} .)\end{array}$} \\
\hline & $\begin{array}{c}\text { Numbers } \\
\left(10^{6} / \mathrm{ml} .\right)\end{array}$ & $\begin{array}{l}\text { Weight } \\
(\mu \mathrm{g} . \mathrm{C} / \mathrm{ml} .)\end{array}$ & & \\
\hline 0 & I.5 & - & 0 & - \\
\hline 50 & 177 & $6 \cdot 2$ & $6 \cdot 3$ & $12 \cdot 5$ \\
\hline 100 & 308 & 10.8 & 15.8 & 26.6 \\
\hline
\end{tabular}

\section{DISCUSSION}

In cultures which have oxidized $50 \mathrm{~mm}$ nitrite we may calculate a free energy balance as follows: free energy not dissipated as heat (from calorimetric determination of the molar heat of substrate oxidation) = Io kcal.; free energy content of extracellular carbon $=\mathbf{I} \cdot 3 \mathrm{kcal}$. For the latter figure we assume that the free energy of compounds excreted into the culture medium is about $100 \mathrm{kcal} . / \mathrm{mole}$ of $\mathrm{C}$. There remains synthesis of $3 \times 10^{12}$ cells per mole of substrate $8.7 \mathrm{kcal}$, , equivalent to $2.9 \times 10^{-9} \mathrm{cal}$./ bacterium for its free energy content. Since the enthalpy change for the combustion of the cell material is about - I IO kcal./mole of carbon (the percentage of which is $50 \%$ ) the heat of combustion/cell will be $-0.3 \times 10^{-9} \mathrm{cal}$. The changes corresponding to the synthesis of one bacterium from $\mathrm{CO}_{2}$, water and minerals are: $\Delta G=2.9 \times 10^{-9}$ cal., $\Delta H=0.3 \times 10^{-9} \mathrm{cal}$., $T \Delta S=-2.6 \times 10^{-9} \mathrm{cal}$. This endergonic reaction is made possible by being coupled to nitrite oxidation, the efficiency of the coupling process being about $50 \%$ in the later stages of the culture.

The calculation above is not unlike that presented by Linschitz (I953) for the information content of a bacterium, the upper limit of which was $10^{13}$ bits. About half that value $\left(4 \times \mathrm{IO}^{12}\right)$ may be calculated from the results presented above.

At the onset of growth, more free energy was dissipated as heat and three times as many bacteria were formed in comparison with the later stages of growth, the free energy content of a bacterium was then noticeably lower, i.e. $0.45 \times 10^{-9} \mathrm{cal}$./cell. It is unlikely that the enthalpy content was much lower at the onset of growth since volume and composition showed no dramatic difference with respect to later stages. The lesser information content of cells at the onset of growth may be correlated with a smaller degree of differentiation of the organelles, especially the membrane system.

A comparison may also be made between the free energy content of a Nitrobacter and the expenditure of free energy necessary for obtaining a heterotrophic bacterium from preformed monomers. The so-called $Y_{\text {ATP }}$ value affords the easiest way for making such a comparison. One mole of ATP leads to the synthesis of very nearly Io g. bacteria (see Stouthamer, I969). This is equivalent to about O. I nanocal./organism for the upper limit of the difference between the free energy of a bacterium and that of its monomers. The free energy of the monomers entering into the synthesis of a Nitrobacter cannot be very different from its enthalpy of combustion of 0.3 nanocal. (above). Consequently, the free energy content of one Nitrobacter is $0.45-0.3=0.15$ 
nanocal. when the expenditure of free energy for synthesis of its monomers is disregarded. It is then in good agreement with that of a heterotrophic bacterium at the onset of its growth but becomes larger at later stages.

\section{REFERENCES}

Calvet, E. \& Prat, H. (1956). Microcalorimétrie: Applications Physico-chimiques et Biologiques. Paris: Masson.

FORREST, W. W. (1970). Entropy of microbial growth. Nature, London 225, I I65-I 166.

JoNes, P. C. T. \& Mollison, J. E. (1948). A technique for the quantitative estimation of soil microorganisms. Journal of General Microbiology 2, 54-69.

Laudelout, H., Simonart, P. C. \& VAN DroogenBroeck, R. (1968). Calorimetric measurement of free energy utilization by Nitrosomonas and Nitrobacter. Archiv für Mikrobiologie 63, 256-277.

LinschITZ, H. (1953). Information content of a bacterial cell. In Information Theory in Biology. Edited by H. Quastler. Urbana: University of Illinois Press.

STOUTHAMER, A. H. (1969). Determination and significance of molar growth yields. In Methods in Microbiology vol. I, pp. 629-663. Edited by J. R. Norris \& D. W. Ribbons, London: Academic Press.

PoE, M. \& EstabrooK, R. W. (I968). Kinetic studies of temperature changes and oxygen uptake concomitant with substrate oxidation by mitochondria: the enthalpy of succinate oxidation during ATP formation by mitochondria. Archives of Biochemistry and Biophysics 126, 320-330.

PORTer, R. J. (1946). Bacterial Chemistry and Physiology. New York: Wiley. 